\title{
Usefulness of Serum Calcitonin in Patients Without a Suspicious History of Medullary Thyroid Carcinoma and with Thyroid Nodules Without an Indication for Fine-Needle Aspiration or with Benign Cytology
}

Authors

Affiliation

\author{
P. W. Rosario, M. R. Calsolari
}

Santa Casa de Belo Horizonte, Minas Gerais, Brazil
Key words

- serum calcitonin

- thyroid nodule

medullary thyroid carcinoma received 16.02.2016 accepted 19.04.2016

Bibliography DOI http://dx.doi.org/ 10.1055/s-0042-107246 Published online: May 20, 2016 Horm Metab Res 2016; 48: 372-376 (c) Georg Thieme Verlag KG Stuttgart · New York ISSN 0018-5043

\section{Correspondence}

\section{P. W. Rosario, MD}

Instituto de Ensino e Pesquisa da Santa Casa de Belo Horizonte

Rua Domingos Vieira, 590

Santa Efigênia. CEP 30150-240

Belo Horizonte

Minas Gerais

Brazil

Tel.: +55/31/32388 819

Fax: $+55 / 31 / 32388980$

pedrowsrosario@gmail.com

\section{Abstract}

$\nabla$

This study evaluated the usefulness of serum calcitonin (Ctn) in subjects without a suspicious history of medullary thyroid carcinoma (MTC) and with nodular thyroid disease without an indication for fine-needle aspiration (FNA) or with benign cytology. This was a prospective study that evaluated 421 patients with nodular disease without an indication for FNA and 602 patients with benign cytology. Patients with basal Ctn $>10 \mathrm{pg} /$ $\mathrm{ml}$ were submitted to calcium stimulation testing. Patients with stimulated $\mathrm{Ctn}>100 \mathrm{pg} / \mathrm{ml}$ were submitted to total thyroidectomy. Basal Ctn was $<10 \mathrm{pg} / \mathrm{ml}$ in 1001 patients (97.8\%). Among patients with basal Ctn $>10 \mathrm{pg} / \mathrm{ml}, 16 / 22$ exhib-

\section{Introduction}

$\nabla$

In subjects with thyroid nodules, elevated serum calcitonin (Ctn) in the absence of another apparent cause raises the suspicion of medullary thyroid carcinoma (MTC), even when other data do not suggest this diagnosis. The usefulness of $\mathrm{Ctn}$ is consensual in patients with a suspicious history or cytology for MTC. Measurement of Ctn has also been recommended for patients referred for thyroidectomy $[1,2]$. Thus, measurement of Ctn is more controversial in the case of subjects without a suspicious history of MTC and without an indication for surgery. Most of these patients have nonvoluminous nodules without an indication for fine-needle aspiration (FNA) or with benign cytology. It is exactly in these subjects that the finding of hypercalcitoninemia could radically modify management, from the expectant management to total thyroidectomy with cervical lymph node dissection [3], and prevent delays in the diagnosis and treatment of MTC, increasing the chance of cure [4].

However, the cost of Ctn measurement (basal and after stimulation in some cases), which needs to ited stimulated $\mathrm{Ctn}>100 \mathrm{pg} / \mathrm{ml}$. Two of these 16 patients had MTC. The 2 patients with MTC had undetectable basal Ctn 6 months after surgery. Using a cut-off of $30 \mathrm{pg} / \mathrm{ml}$ in women and $60 \mathrm{pg} /$ $\mathrm{ml}$ in men for basal Ctn, the 2 cases of MTC of our series would have been identified and there would have been no false-positive case. It should be noted that $14 / 16$ patients with stimulated $\mathrm{Ctn}>100 \mathrm{pg} / \mathrm{ml}$ were false-positive cases. Although uncommon, even subjects without a suspicious history and with nodular thyroid disease without an indication for FNA or with benign cytology can have MTC. The measurement of Ctn permits the diagnosis of these cases. Our results favor the hypothesis that basal Ctn could be superior to stimulated Ctn.

be performed in hundreds of patients in order to detect one case of MTC exclusively by this method, and the risk of false-positive results are limitations of routine Ctn measurement in patients with thyroid nodules. The different position statements on this topic in current guidelines $[1,2,5,6]$ clearly demonstrate that more studies are desirable.

The objective of this prospective study was to evaluate the usefulness of Ctn in subjects without a suspicious history of MTC and with nodular thyroid disease without an indication for FNA or with benign cytology, and without an indication for surgery.

\section{Patients and Methods \\ $\nabla$ \\ Design}

This was a prospective study. The selection criteria and follow-up protocol of the patients were pre-defined and rigorously followed. The study was approved by the Research Ethics Committee of our institution. 


\section{Patients}

First, patients with nodular thyroid disease consecutively seen by the first author (P.W.R.) were evaluated. Excluded were (i) patients with a family history of MTC or type 2 multiple endocrine neoplasia or a clinical suspicion of the latter; (ii) patients previously operated for thyroid carcinoma; (iii) patients who had only hot nodules on ${ }^{131}$ I scintigraphy (performed on patients with low TSH); (iv) patients who had only purely cystic nodules; and $(\mathrm{v})$ patients with known presence of kidney failure, hyperparathyroidism, neuroendocrine tumor, or lung cancer $[7,8]$. Among the remaining patients, those without an indication for FNA (Group 1) or with benign cytology (Group 2) were included. Nodules that did not require FNA were: (i) hot nodules on ${ }^{123}$ I scintigraphy (performed on patients with low TSH); (ii) purely cystic nodules; (iii) spongiform nodules $<2 \mathrm{~cm}$; (iv) nodules without suspicious features (intense hypoechogenicity, microcalcifications, irregular margins, predominantly or exclusively intranodal vascularization, anteroposterior diameter larger than transverse diameter), and (a) hypoechoic solid or predominantly solid $<1 \mathrm{~cm}$, or (b) iso- or hyperechoic $<1.5 \mathrm{~cm}$, or (c) complex $<2 \mathrm{~cm}$. Considering the objective of this study, patients with a surgical indication due to voluminous nodule(s) were not included.

\section{Measurement of Ctn}

Serum Ctn was measured in all patients. For Ctn measurement, the patients were asked not to consume alcohol for at least one week and to discontinue the use of proton pump inhibitors for at least 4 weeks $[7,8]$. None of the patients had apparent bacterial infection or hypercalcemia at the time of measurement. The serum samples were obtained in the morning (at about 8:00 AM) after an 8- to 10-h fast and were analyzed immediately after collection. Patients with basal Ctn $>10 \mathrm{pg} / \mathrm{ml}$ underwent a calcium stimulation test [rapid venous infusion of $2.5 \mathrm{mg}$ calcium/ $\mathrm{kg}$ in the form of $10 \%$ calcium gluconate $(10 \mathrm{ml} / \mathrm{min})$ ] [7]. Serum Ctn was measured before and 2, 5, and $10 \mathrm{~min}$ after calcium infusion [7].

\section{Management}

Patients initially exempted from FNA, but with basal Ctn $>10 \mathrm{pg} /$ $\mathrm{ml}$, were submitted to this procedure. Patients with stimulated Ctn $>100 \mathrm{pg} / \mathrm{ml}$ underwent thyroidectomy combined with elective dissection of the cervical lymph nodes (indicated exclusively based on the finding of hypercalcitoninemia [3]). Ultrasonography (US) and Ctn were repeated after 1 year in patients with basal Ctn $>10 \mathrm{pg} / \mathrm{ml}$ and stimulated Ctn $<100 \mathrm{ng} / \mathrm{ml}$.

\section{Assay}

Serum Ctn was measured by an immunochemiluminescent assay (Immulite, Diagnostic Products Corporation, Los Angeles, CA, USA), with a sensitivity of $2 \mathrm{pg} / \mathrm{ml}$ and reference values of up to $5 \mathrm{pg} / \mathrm{ml}$ for women and $8.4 \mathrm{pg} / \mathrm{ml}$ for men.

\section{Sonography}

Sonography was performed with a linear multifrequency transducer for morphological analysis (B-mode) and for power Doppler evaluation.

\section{FNA}

FNA was performed with a 22-gauge needle and a 5 or $10 \mathrm{ml}$ syringe, and was guided by US fine-needle aspiration biopsy of thyroid nodules. The smears (cytology and histology) were analyzed by pathologists experienced in thyroid pathology.

\section{Results \\ $\nabla$}

\section{Group 1 (patients without an indication for FNA)}

A total of 421 patients (341 women and 80 men) ranging in age from 12 to 76 years (median 44 years) were evaluated.

Basal Ctn was $<10 \mathrm{pg} / \mathrm{ml}$ in 413 patients ( $98.1 \%$ ). In the 8 patients with basal $\mathrm{Ctn}>10 \mathrm{pg} / \mathrm{ml}$, FNA performed exclusively based on the finding of elevated Ctn did not suspect malignancy. In the 2 patients with stimulated $\mathrm{Ctn}<100 \mathrm{pg} / \mathrm{ml}$ and benign cytology who were not submitted to surgery, there was no increase in the size of nodules and basal Ctn was $<10 \mathrm{pg} / \mathrm{ml}$ after 1 year. MTC was excluded by histology in one patient with stimulated $\mathrm{Ctn}<100 \mathrm{pg} / \mathrm{ml}$ and indeterminate cytology and in the 4 patients with stimulated $\mathrm{Ctn}>100 \mathrm{pg} / \mathrm{ml}$ and benign cytology. One patient with basal Ctn of $81 \mathrm{pg} / \mathrm{ml}$ and stimulated Ctn of $1070 \mathrm{pg} /$ $\mathrm{ml}$ had MTC; in this patient, basal Ctn was undetectable 6 months after surgery. The data of the patients of group 1 with basal Ctn $>10 \mathrm{pg} / \mathrm{ml}$ are shown in $\odot$ Table 1.

\section{Group 2 (patients with benign cytology)}

A total of 602 patients ( 482 women and 120 men) ranging in age from 12 to 78 years (median 48 years) were evaluated.

Basal Ctn was $<10 \mathrm{pg} / \mathrm{ml}$ in 588 patients (97.7\%). Fourteen patients had basal $\mathrm{Ctn}>10 \mathrm{ng} / \mathrm{ml}$. Eleven patients with stimulated $\mathrm{Ctn}>100 \mathrm{pg} / \mathrm{ml}$ were submitted to total thyroidectomy with elective dissection of the cervical lymph nodes and histology confirmed MTC in one patient and C-cell hyperplasia in 2 patients. Basal Ctn was undetectable in these 3 patients 6

\begin{tabular}{|c|c|c|c|c|c|c|c|c|}
\hline Sex & $\begin{array}{l}\text { Age } \\
\text { (years) }\end{array}$ & $\begin{array}{l}\text { Number of } \\
\text { Nodules }\end{array}$ & Size $(\mathrm{mm})^{\dagger}$ & $\begin{array}{l}\text { Basal Ctn } \\
(\mathrm{pg} / \mathrm{ml})\end{array}$ & $\begin{array}{l}\text { Stimulated } \\
\text { Ctn (pg/ml) }\end{array}$ & Cytology & Histology & $\begin{array}{l}\text { Table } 1 \text { Data of patients who } \\
\text { initially had no indication for FNA } \\
\text { (Group 1) and basal serum calci- }\end{array}$ \\
\hline $\mathrm{F}$ & 34 & 3 & 5,6, and 11 & 11 & 23 & Indeterminate & CG & tonin $>10 \mathrm{pg} / \mathrm{ml}$. \\
\hline $\mathrm{F}$ & 23 & 1 & 8 & 13 & 25 & Benign & NA & \\
\hline $\mathrm{F}$ & 49 & 2 & 7 and 12 & 13 & 123 & Benign & $\mathrm{CG}+\mathrm{FA}$ & \\
\hline $\mathrm{F}$ & 36 & 2 & 6 and 17 & 15 & 78 & Benign & NA & \\
\hline $\mathrm{F}$ & 28 & 1 & 8 & 16 & 156 & Benign & CG & \\
\hline $\mathrm{F}$ & 54 & 1 & 7 & 18 & 102 & Benign & CG & \\
\hline M & 45 & 2 & 5 and 8 & 28 & 229 & Benign & CG & \\
\hline M & 63 & 1 & 15 & 81 & 1070 & Insufficient & MTC (stage T1N1aM0) & \\
\hline
\end{tabular}




\begin{tabular}{|c|c|c|c|c|c|c|c|}
\hline Sex & Age (years) & $\begin{array}{l}\text { Number of } \\
\text { nodules }\end{array}$ & Size $(\mathrm{mm})^{\dagger}$ & Basal Ctn (pg/ml) & $\begin{array}{l}\text { Stimulated Ctn } \\
(\mathrm{pg} / \mathrm{ml})\end{array}$ & Histology & $\begin{array}{l}\text { Table } 2 \text { Data of patients with } \\
\text { benign cytology (Group } 2 \text { ) and } \\
\text { basal serum calcitonin }>10 \mathrm{pg} / \mathrm{ml} \text {. }\end{array}$ \\
\hline$F$ & 29 & 1 & 33 & 12 & 31 & NA & \\
\hline$M$ & 50 & 1 & 28 & 14 & 156 & CG & \\
\hline$F$ & 61 & 2 & 22 and 30 & 14 & 45 & NA & \\
\hline $\mathrm{F}$ & 35 & 4 & $8,10,12,25$ & 16 & 214 & $\mathrm{PMC}+\mathrm{CG}$ & \\
\hline$M$ & 38 & 1 & 17 & 17 & 170 & FA & \\
\hline $\mathrm{F}$ & 70 & 3 & $9,26,32$ & 18 & 242 & $\mathrm{PMC}+\mathrm{FA}+\mathrm{CG}$ & \\
\hline $\mathrm{F}$ & 62 & 2 & 14,27 & 20 & 341 & CG & \\
\hline $\mathrm{F}$ & 42 & 1 & 14 & 21 & 82 & NA & \\
\hline M & 24 & 1 & 18 & 21 & 309 & CG & \\
\hline$F$ & 54 & 1 & 20 & 23 & 358 & CG & \\
\hline $\mathrm{F}$ & 65 & 2 & 8 and 16 & 28 & 521 & $C G+F A$ & \\
\hline M & 51 & 1 & 8 & 30 & 432 & $\mathrm{CCH}+\mathrm{CG}$ & \\
\hline M & 45 & 2 & 9 and 15 & 32 & 585 & $\mathrm{CCH}+\mathrm{CG}$ & \\
\hline $\mathrm{F}$ & 49 & 1 & 12 & 43 & 381 & $\begin{array}{l}\text { MTC (stage } \\
\text { T1NOM0) }\end{array}$ & \\
\hline
\end{tabular}

months after surgery. In the 3 patients with stimulated $\mathrm{Ctn}<100 \mathrm{pg} / \mathrm{ml}$ who were not submitted to surgery, there was no increase in the size of nodules and basal Ctn was $<10 \mathrm{pg} / \mathrm{ml}$ $(n=2)$ or remained stable $(n=1)$ after 1 year.

- Table 2 shows the data of the patients of group 2 with basal Ctn $>10 \mathrm{pg} / \mathrm{ml}$. Using a cut-off of $30 \mathrm{pg} / \mathrm{ml}$ in women and $60 \mathrm{pg} /$ $\mathrm{ml}$ in men for basal Ctn, the 2 cases of MTC of our series would have been identified and there would have been no false-positive case. It should be noted that 14 of our 16 patients with calcium-stimulated $\mathrm{Ctn}>100 \mathrm{pg} / \mathrm{ml}$ were false-positive cases.

\section{Discussion \\ $\nabla$}

The present study only included subjects with nodular thyroid disease without an indication for FNA or with benign cytology, and without an indication for surgery. The need for Ctn is more controversial in this group. In fact, the usefulness of Ctn is consensual in patients with a suspicious history or cytology for MTC and its measurement has also been recommended for patients referred for thyroidectomy $[1,2]$. In the patients evaluated in this series whose recommended management is expectant, the measurement of Ctn may have a greater prognostic impact since eventual MTC will only be diagnosed and treated in the case of tumor progression. In addition to the selection criterion of the patients, we highlight the fact that the study was prospective, the protocol used for the collection and processing of the samples for Ctn measurement, and the fact that stimulation testing was performed in all subjects with basal $\mathrm{Ctn}>10 \mathrm{pg} / \mathrm{ml}$ and that histology was obtained from all patients with Ctn $>100 \mathrm{pg} / \mathrm{ml}$.

The American Thyroid Association [6] exempts FNA in the case of infracentimetric nodules, and sporadic microcarcinomas are therefore no longer diagnosed. However, the clinical impact of sporadic medullary microcarcinomas has been demonstrated by the significant rates of lymph node metastases, persistent disease, and distant metastases and death even in the case of immediate surgical treatment after diagnosis [9-13]. Some macrocarcinomas may also not be readily diagnosed. FNA is not necessary in the case of iso- or hyperechoic solid nodules $<1.5 \mathrm{~cm}$ or complex nodules $<2 \mathrm{~cm}$ without suspicious ultrasonographic features [6], and 25\% of MTC exhibit this ultrasonographic appearance [14-16]. Even if FNA is performed, it is able to detect approximately one-half of MTC lesions [17] and approximately $10 \%$ of MTC may have their cytology interpreted as benign $[4,16,18-21]$. The measurement of $C$ tn permits to diagnose MTC in these situations (FNA not indicated or false-negative cytology), as observed in the 2 cases of the present series.

Basal Ctn $<10 \mathrm{pg} / \mathrm{ml}$ renders sporadic MTC very unlikely $[4,7$, $18,22]$. Traditionally, this diagnosis is suspected when basal Ctn $>10 \mathrm{pg} / \mathrm{ml}$, but some authors recommend investigation for sporadic MTC only when basal Ctn concentrations are $>15 \mathrm{pg} / \mathrm{ml}$ [23] or $>20 \mathrm{pg} / \mathrm{ml}[22,24]$. At the other end, in the absence of an apparent cause (such as chronic renal failure, use of proton pump inhibitors, other known secretory tumors), basal Ctn $>100 \mathrm{pg} / \mathrm{ml}$ has a high positive predictive value (PPV) for MTC $[4,7,18,19,22,25]$. Despite this traditional cut-off value, its reduction has been proposed by some authors since a very high PPV already exists for concentrations less than $100 \mathrm{pg} / \mathrm{ml}$ [24,25].

For patients with mild or moderate hypercalcitoninemia, measurement of Ctn after stimulation (traditionally with pentagastrin) is recommended and stimulated $\mathrm{Ctn}<100 \mathrm{pg} / \mathrm{ml}$ makes sporadic MTC unlikely. Although some studies have shown an excellent PPV of stimulated Ctn $>100 \mathrm{pg} / \mathrm{ml}[4,18]$, false-positive results have been reported frequently and higher cut-off values have been proposed [22,25].

In the present study, all 22 patients with basal Ctn between 10 and $100 \mathrm{pg} / \mathrm{ml}$ received venous infusion of calcium for the stimulation test. In countries where pentagastrin is not readily available, although its importation is possible, calcium can be used for stimulation testing. In addition to being a known stimulus of Ctn secretion, calcium may be better tolerated [26, 27]. However, calcium seems to be a more potent stimulus than pentagastrin $[26,28]$, a fact leading to a larger number of false-positive results if the same cut-off were adopted and, consequently, to more unnecessary surgeries. Indeed, among patients with basal Ctn between 10 and $100 \mathrm{pg} / \mathrm{ml}$ who are exactly candidates for stimulation testing, all 5 men and 9/15 women without MTC had stimulated Ctn>100 pg/ml, showing that this Ctn cut-off after stimulation with calcium seems to be low when the indication for surgery or extension of surgery is based exclusively on this finding. 
Some authors question the additional value of stimulated Ctn compared to basal Ctn $[29,30]$ and propose the latter to be sufficient, especially if the cut-off is adjusted for sex [30]. Using basal Ctn for the definition of management, many patients can be exempt from stimulation testing; in this series, approximately $2 \%$. Our results indeed favor the hypothesis that basal Ctn could be superior to stimulated Ctn. Using a cut-off value of approximately $30 \mathrm{pg} / \mathrm{ml}$ in women and $60 \mathrm{pg} / \mathrm{ml}$ in men as proposed recently [30], the 2 cases of MTC of our series would have been identified and there would have been no false-positive case. It should be noted that 14 of our 16 patients with calcium-stimulated $\mathrm{Ctn}>100 \mathrm{pg} / \mathrm{ml}$ were false-positive cases.

In patients with nodular thyroid disease and only moderately elevated Ctn, the measurement of Ctn in aspiration needle washout (FNA-Ctn) is an excellent alternative to stimulation testing, showing a sensitivity of $98 \%$ [16,31]. Compared to stimulation tests, FNA-Ctn has the advantages of greater ease of use, absence of adverse effects (related to pentagastrin or calcium), and lower cost. Moreover, false-positive cases are uncommon with this diagnostic test [16,31].

Regardless of which is the best management for patients with only moderately elevated Ctn (define management based on basal Ctn, obtained stimulated Ctn, or obtained FNA-Ctn), we recognize that in the patients studied (with benign cytology or without an indication for FNA), each diagnosed case of MTC had a cost of approximately 500 measurements of Ctn. Although one should not minimize the costs that could be avoided with the early diagnosis and treatment of MTC [32], the cost-effectiveness of routine Ctn measurement should be better analyzed and may be different in each country [32].

We conclude that measurement of Ctn may diagnose sporadic MTC even in patients without a suspicious history and with nodules without an indication for FNA or with benign cytology.

\section{Funding}

$\nabla$

This research did not receive any specific grant from any funding agency in the public, commercial or not-for-profit sector.

\section{Conflict of Interest}

$\nabla$

The authors declare that there is no conflict of interest.

\section{References}

1 Pacini F, Schlumberger M, Dralle $H$, Elisei R, Smit JW, Wiersinga W. European consensus for the management of patients with differentiated thyroid carcinoma of the follicular epithelium. Eur J Endocrinol 2006; 154: 787-803

2 Gharib H, Papini E, Paschke R, Duick DS, Valcavi R, Hegedüs L, Vitti P. American Association of Clinical Endocrinologists, Associazione Medici Endocrinologi, and European Thyroid Association Medical guidelines for clinical practice for the diagnosis and management of thyroid nodules: executive summary of recommendations. Endocr Pract 2010; 16: 1-43

3 Wells ASJr, Asa SL, Dralle H, Elisei R, Evans DB, Gagel RF, Lee NY, Machens A, Moley JF, Pacini F, Raue F, Frank-Raue K, Robinson B, Rosenthal S, Santoro M, Schlumberger M, Shah MH, Waguespack SG. Revised American Thyroid Association Guidelines for the Management of Medullary Thyroid Carcinoma The American Thyroid Association Guidelines Task Force on Medullary Thyroid Carcinoma. Thyroid 2015; 25: 567-610
4 Elisei R, Bottici V, Luchetti F, Di Coscio G, Romei C, Grasso L, Miccoli P, Iacconi P, Basolo F, Pinchera A, Pacini F. Impact of routine measurement of serum calcitonin on the diagnosis and outcome of medullary thyroid cancer: experience in 10,864 patients with nodular thyroid disorders. J Clin Endocrinol Metab 1994; 89: 163-168

5 Perros P, Boelaert K, Colley S, Evans C, Evans RM, Gerrard BaG, Gilbert J, Harrison B, Johnson SJ, Giles TE, Moss L, Lewington V, Newbold K, Taylor J, Thakker RV, Watkinson J, Williams GR, British Thyroid Association. Guidelines for the management of thyroid cancer. Clin Endocrinol (Oxf) 2014; 81 (Suppl 1): 1-122

6 Haugen BR, Alexander EK, Bible KC, Doherty G, Mandel SJ, Nikiforov YE, Pacini F, Randolph G, Sawka A, Schlumberger M, Schuff KG, Sherman SI, Sosa JA, Steward D, Tuttle RM, Wartofsky L. American Thyroid Association Management Guidelines for Adult Patients with Thyroid Nodules and Differentiated Thyroid Cancer. Thyroid 2016; 26: 1-133

7 Rosario PW, Penna GC, Brandão K, Souza BÉ. Usefulness of preoperative serum calcitonin in patients with nodular thyroid disease without suspicious history or cytology for medullary thyroid carcinoma. Arq Bras Endocrinol Metabol 2013; 57: 312-316

8 Rosario PW, Calsolari MR. Influence of chronic autoimmune thyroiditis and papillary thyroid cancer on serum calcitonin levels. Thyroid 2013; 23: 671-674

9 Beressi N, Campos JM, Beressi JP, Franc B, Niccoli-Sire P, Conte-Devolx $B$, Murat A, Caron P, Baldet L, Kraimps JL, Cohen R, Bigorgne JC, Chabre $O$, Lecomte $P$, Modigliani E. Sporadic medullary microcarcinoma of the thyroid: a retrospective analysis of eighty cases. Thyroid 1998; 8: 1039-1044

10 Guyétant S, Dupre F, Bigorgne JC, Franc B, Dutrieux-Berger N, LecomteHoucke M, Patey M, Caillou B, Viennet G, Guerin O, Saint-Andre JP. Medullary thyroid microcarcinoma: a clinicopathologic retrospective study of 38 patients with no prior familial disease. Hum Pathol 1999; 30: 957-963

11 Machens A, Dralle H. Biological relevance of medullary thyroid microcarcinoma. J Clin Endocrinol Metab 2012; 97: 1547-1553

12 Kazaure HS, Roman SA, Sosa JÁ. Medullary thyroid microcarcinoma: a population-level analysis of 310 patients. Cancer 2012; 118: 620-627

13 Saltiki K, Rentziou G, Stamatelopoulos K, Georgiopoulos G, Stavrianos C, Lanbrinoudaki E, Alevizaki M. Small medullary thyroid carcinoma (MTC): postoperative calcitonin rather than tumour size predict disease persistence and progression. Eur J Endocrinol 2014; 171: 117-126

14 Lee S, Shin JH, Han BK, Ko EY. Medullary thyroid carcinoma: comparison with papillary thyroid carcinoma and application of current sonographic criteria. AJR Am J Roentgenol 2010; 194: 1090-1094

15 Choi N, Moon WJ, Lee JH, Baek JH, Kim DW, Park SW. Ultrasonographic findings of medullary thyroid cancer: differences according to tumor size and correlation with fine needle aspiration results. Acta Radiol 2011; 52: 312-316

16 Trimboli P, Cremonini N, Ceriani L, Saggiorato E, Guidobaldi L, Romanelli $F$, Ventura C, Laurenti $O$, Messuti I, Solaroli E, Madaio R, Bongiovanni $M$, Orlandi F, Crescenzi A, Valabrega S, Giovanella L. Calcitonin measurement in aspiration needle washout fluids has higher sensitivity than cytology in detecting medullary thyroid cancer: a retrospective multicentre study. Clin Endocrinol (Oxf) 2014; 80: 135-140

17 Trimboli P, Treglia G, Guidobaldi L, Romanelli F, Nigri G, Valabrega S, Sadeghi R, Crescenzi A, Faquin WC, Bongiovanni M, Giovanella L. Detection rate of FNA cytology in medullary thyroid carcinoma: a metaanalysis. Clin Endocrinol (Oxf) 2015; 82: 280-285

18 Niccoli P, Wion-Barbot N, Caron P, Henry JF, De Micco E, Saint Andre JP, Bigorgne JC, Modigliani E, Conte-Devolx B. Interest of routine measurement of serum calcitonin: study in a large series of thyroidectomized patients. J Clin Endocrinol Metab 1997; 82: 338-341

19 Henry JF, Denizot A, Puccini M, Gramatica L, Kvachenyuk A, Conte Devolx $B$, De Micco C. Latent subclinical medullary thyroid carcinoma: diagnosis and treatment. World J Surg 1998; 22: 752-756

20 Bugalho MJ, Santos JR, Sobrinho L. Preoperative diagnosis of medullary thyroid carcinoma: fine needle aspiration cytology as compared with serum calcitonin measurement. J Surg Oncol 2005; 91: 56-60

21 Essig GF, Porter K, Schneider D, Debora A, Lindsey SC, Busonero G Fineberg D, Fruci B, Boelaert K, Smit JW, Meijer JA, Duntas L, Sharma $N$, Costante G, Filetti S, Sippel RS, Biondi B, Topliss DJ, Pacini F, Maciel $R M$, Walz PC, Kloos RT. Fine needle aspiration and medullary thyroid carcinoma: the risk of inadequate preoperative evaluation and initial surgery when relying upon FNAB cytology alone. Endocr Pract 2013; 19: $920-927$ 
22 Costante G, Meringolo D, Durante C, Bianchi D, Nocera M, Tumino S, Crocetti U, Attard M, Maranghi M, Torlontano M, Filetti S. Predictive value of serum calcitonin levels for preoperative diagnosis of medullary thyroid carcinoma in a cohort of 5817 consecutive patients with thyroid nodules. J Clin Endocrinol Metab 2007; 92: 450-455

23 Rink T, Truong PN, Schroth HJ, Diener J, Zimny M, Grunwald F. Calculation and validation of a plasma calcitonin limit for early detection of medullary thyroid carcinoma in nodular thyroid disease. Thyroid 2009; 19: 327-332

24 Ahmed SR, Ball DW. Clinical review: Incidentally discovered medullary thyroid cancer: diagnostic strategies and treatment. J Clin Endocrinol Metab 2011; 96: 1237-1245

25 Scheuba C, Kaserer K, Moritz A, Drosten R, Vierhapper H, Bieglmayer $C$, Haas OA, Niederle B. Sporadic hypercalcitoninemia: clinical and therapeutic consequences. Endocr Relat Cancer 2009; 16: 243-253

26 Doyle P, Duren C, Nerlich K, Verburg FA, Grelle I, Jahn H, Fassnacht $M$, Mäder U, Reiners C, Luster M. Potency and tolerance of calcitonin stimulation with high-dose calcium vs. pentagastrin in normal adults. J Clin Endocrinol Metab 2009; 94: 2970-2974

27 Colombo C, Verga U, Mian C, Ferrero S, Perrino M, Vicentini L, Dazzi $D$, Opocher G, Pelizzo MR, Beck-Peccoz P, Fugazzola L. Comparison of calcium and pentagastrin tests for the diagnosis and follow-up of medullary thyroid cancer. J Clin Endocrinol Metab 2012; 97: 905-913
28 Lorenz K, Elwerr M, Machens A, Abuazab M, Holzhausen HJ, Dralle H. Hypercalcitoninemia in thyroid conditions other than medullary thyroid carcinoma: a comparative analysis of calcium and pentagastrin stimulation of serum calcitonin. Langenbecks Arch Surg 2013; 398: 403-409

29 Chambon G, Alovisetti C, Idoux-Louche C, Reynaud C, Rodier M, Gued $A M$, Chapuis $H$, Lallemant JG, Lallemant B. The use of preoperative routine measurement of basal serum thyrocalcitonin in candidates for thyroidectomy due to nodular thyroid disordes: results from 2733 consecutive patients. J Clin Endocrinol Metab 2011; 96: 75-81

30 Mian C, Perrino M, Colombo C, Cavedon E, Pennelli G, Ferrero S, De Leo S, Sarais C, Cacciatore C, Irene Manfredi G, Verga U, Iacobone M, De Pasquale L, Pelizzo MR, Vicentini L, Persani L, Fugazzola L. Refining calcium test for the diagnosis of medullary thyroid cancer: cut-offs, procedures and safety. J Clin Endocrinol Metab 2014; 99: 1656-1664

31 Trimboli P, Guidobaldi L, Bongiovanni M, Crescenzi A, Alevizaki M, Giovanella $L$. Use of fine-needle aspirate calcitonin to detect medullary thyroid carcinoma: A systematic review. Diagn Cytopathol 2016; 44: $45-51$

32 Cheung K, Roman SA, Wang TS, Walker HD, Sosa JA. Calcitonin measurement in the evaluation of thyroid nodules in the United States: a cost-effectiveness and decision analysis. J Clin Endocrinol Metab 2008; 93: 2173-2180 